\section{Ewa Graczyk}

Uniwersytet Gdański

\title{
Opętani: żeby nastąpił wybuch, musimy potrząsać całością
}

\section{Abstract \\ Opętani: For an Explosion to Happen, We Must Shake the Whole}

The article attempts to prove that the novel Opetani (Posessed) is crucial to understanding the whole of Gombrowicz's writings. The novel almost openly represents homosexual desire and the characteristic variegation and fragmentariness of the author's message is a strategy that was used by Gombrowicz consistently since then.

Słowa kluczowe: Witold Gombrowicz, queer studies, kamp, biografia a twórczość Keywords: Witold Gombrowicz, queer studies, camp, biography and literary production 
Można powiedzieć, poszerzając i parafrazując terminologię samego Witolda Gombrowicza, że pisarz przez całe swoje twórcze życie posługuje się trzema taktykami, działa według trzech reguł. Po pierwsze, najczęściej - po bożemu jednak - jest wielkim elitarnym twórcą występującym $w$ gronie innych wybitnych wybrańców. Jako taki działa według logiki, którą nazwę: „,im mądrzej, tym mądrzej”. Po drugie, korzystając ze swojej świetnej pozycji, wygłasza pisarz w Dzienniku słynne zdanie mówiące o tym, że „im mądrzej, tym głupiej”. Podważa tą myślą logikę „,im mądrzej, tym mądrzej”. Twórca kieruje tę sentencję także przeciw sobie, stąd odmienność Gombrowiczowskiej formuły od wszelkiego innego wyrzekania na ludzką głupotę.

Autor Ferdydurke jednak znacznie radykalniej, poprzez pisarskie działanie, podważa logikę typu ,im mądrzej, tym mądrzej”, gdy w młodości ciągle na nowo próbuje pisać dobre złe powieści, ponieważ kiedy tak robi, działa według reguły, którą można określić jako ,im głupiej, tym mądrzej”. Ma w zanadrzu dwa rezultaty działania tej logiki, dwa kukułcze jaja: najpierw Opętanych, a potem, po latach, Kronosa. Te niezwykłe teksty funkcjonują na równie niezwykłym marginesie, utrudniając krytykom konstruowanie integralności Gombrowiczowskiego dzieła - i najprawdopodobniej o to twórcy chodziło, o wzmożoną niemożność domknięcia opisu.

Uświadomienie sobie współistnienia tych trzech strategii - „im mądrzej, tym mądrzej”, ,im mądrzej, tym głupiej” oraz „,im głupiej, tym mądrzej” rodzi pytanie, jakie relacje panują między nimi, jak ma się arystokrata ducha, awangardowy artysta i przenikliwy intelektualista do tego, który traci, zyskując, i tego, kto zyskuje na głupich decyzjach. Warto pytać o znaczenie każdej z tych strategii i zastanowić się, co razem z nich wynika. Pozwoli to połączyć ze sobą dywersyjność myśli „im mądrej, tym głupiej” ze szczególną dziurą w serze, którą jest powieść Opętani, a potem Kronos.

Pierwszej logiki prawie nie dostrzegamy, ponieważ jest dla nas oczywista. Dopiero, gdy skonfrontujemy ją z „im mądrzej, tym głupiej” oraz z „im głupiej, tym mądrzej”, zaczynamy widzieć cienie mądrej mądrości. Tak się bowiem składa, że mądry mędrzec zajmuje zazwyczaj niekwestionowaną pozycję kogoś, kto ma prawo głosić to, co głosi. W logikę „im mądrzej, tym mądrzej" wpisany jest automatyzm dodawania plusów, narastająca trudność rewizji swojej postawy i pozycji, nieuchronne usztywnienie oraz zwiększający się problem z uwzględnieniem głosów i racji tych, którzy mają kłopoty z gromadzeniem zasług. Choć kumulacyjna, jest zarazem selektywna i jako taka pozbywa się wielu danych, zjawisk i dzieł.

Podjęcie przez pisarza taktyki „im mądrzej, tym głupiej” oraz ,im głupiej, tym mądrzej" pozwala Gombrowiczowi przeprowadzać rozmaite rewizje dróg kumulacji i postępu, umożliwia odkrywanie sprzeczności i niebezpieczeństw jednorodnie mądrej mądrości. Uzupełnienie ciągu „im mądrzej, tym mądrzej” 
dwiema innymi taktykami pokazuje, że kumulacji musi towarzyszyć co najmniej ograniczone zaufanie do tego, co powszechnie uchodzi za mądre, dobre i piękne. Procesy wartościowania, tradycyjne i inercyjne narastanie znaczeń, ukryte związki porządku siły i władzy z wymiarem aksjologicznym mogą się stać po owym dodaniu do siebie trzech taktyk przedmiotem krytycznej analizy. Okazują się one lustrami tak ustawionymi, że ujawniają słabości tej najważniejszej, pierwszej z nich.

Gombrowicz nie zdążył ogłosić, że był pierwszym dekonstrukcjonistą, ale niewątpliwie miałby do tego prawo.

Powiązałabym ten racjonalny, intelektualny porządek dekonstrukcjonistycznej strategii z wymiarem libidalnym. Tak się bowiem składa, że mądrymi mędrcami okazują się zazwyczaj uprzywilejowani mężczyźni - heteroseksualni, wykształceni, biali. A tak się również składa, że autor Ferdydurke należy do licznej $\mathrm{w}$ okresie międzywojennym i powojennym grupy pisarzy przedemancypacyjnych, którzy w niejawny sposób wyrażali w swoich utworach pożądanie homoseksualne. Jarosław Iwaszkiewicz, Tadeusz Breza, Jerzy Andrzejewski, Gombrowicz to pierwszorzędne przykłady tego zjawiska. German Ritz zwraca uwagę, że dzięki temu, iż pisarze ci kodowali w swoich tekstach pragnienia nieheteronormatywne, zajęli ważne miejsce na szczytach polskiego parnasu literackiego. Dzięki zamaskowaniu nielegalnych treści ,uniwersalna" ranga tych twórców ciągle rosła, pozostawała jednak krucha, gdyż zależała od przebywania w szafie (nawiasem mówiąc, szafa jest najważniejszym meblem w Ferdydurke i Opętanych).

Można więc zapytać, co się stało i staje, gdy, najczęściej po śmierci, pisarze przedemancypacyjni są „outowani” przez swoich biografów i badaczy? Jaką rolę w zmianie ich miejsca na mapie literatury polskiej (zwłaszcza gdy następuje obniżenie rangi) odgrywa ujawnienie po latach? Czy pisarze ci przesuwają się ku gejowskiemu marginesowi i przestają mieć znaczenie „uniwersalne”? Na pewno na zjawisko pośmiertnego czyśćca tej grupy pisarzy, na chwianie się ich rangi, da się spojrzeć i z tego punktu widzenia.

Gombrowicz jakby przygotował się na tę dynamikę recepcji i wrażliwość swojej pozycji. W sposobie, w jaki spreparował odpowiedź zza grobu - myślę tu zwłaszcza o Kronosie - czuć rękę wielkiego performera.

Pojmował siebie (dla nas w trybie lektury pośmiertnej) jako autora Ferdydurke, Ślubu, Kosmosu, a także jako producenta Opętanych i Kronosa. Dla czytelników przez wiele lat był przede wszystkim księciem - Hamletem, jaśnie paniczem, piątym wieszczem polskiej literatury - ale sam siebie definiował również jako żebraka. Kilka lat wędrował przecież ulicami Buenos 
Aires jako polski Genet, parias i włóczęga. We wszystkich jego utworach usłyszeć możemy lament i rechot zamurowanego żebraka. Sam pisarz mówi o tym w Testamencie: „Byłem - i wiedziałem o tym bez najmniejszego zdziwienia i bez cienia protestu - istotą anormalną, która nigdy i wobec nikogo nie może przyznać się do siebie, skazaną na wieczyste ukrywanie się, na konspirację"1. Autor Ferdydurke w swoich trzech odsłonach, trzech taktykach, ujawnia dość odmienne zachowania. Pierwszy - oficjalny geniusz Gombrowicz, mądry mędrzec, korzystający z domniemania, że należy do heteroseksualnej męskiej większości, rywalizuje o wielkość z energią godną najbardziej walecznych efebów Harolda Blooma. Jest surowy, elitarny, wypowiada często sądy, które znakomicie ilustrują jego własną tezę, że „im mądrzej, tym głupiej”, ponieważ np. przy całej błyskotliwości sformułowań to, co pisze o literaturze kobiet, opiera się na stereotypowych, często niesprawiedliwych opiniach, a to, co sądzi o Henryku Sienkiewiczu, w wielu punktach okazuje się zbieżne z opinią Stanisława Brzozowskiego. W roli mędrca, któremu samo rośnie, Gombrowicz bywa „obcinającym” egzaminatorem, mało w nim entuzjazmu Brunona Schulza, wypatrującego śladów cudzego geniuszu. Dojrzały Gombrowicz, konstruujący swoją wielkość, tylko czasami zachowuje ciekawość młodego recenzenta. Mądry mędrzec starannie zawiaduje swoją chwałą, nie pozwala wystawić Ślubu w Kielcach, ponieważ jego wielkość musi eksplodować w stolicy. Drugi, a zwłaszcza trzeci, nieheteroseksualny żebrak, ktoś narażony na stratę, partykularny, a nie „uniwersalny”, nie musi się okazać mizoginem (w Opętanych nie jest, choć w Kronosie tak) i znacznie mniej rywalizuje.

Napisanie przez Gombrowicza Opętanych, element dekonstrukcjonistycznej taktyki pisarza, efekt działania logiki ,im głupiej, tym mądrzej”, sygnał nieufności do jednorodnej aksjologii jest jak dołączenie do Bloomowskiego kanonu geniuszy Elizy Orzeszkowej i Chinua Achebe. Jest subwersywnym podważeniem spójności własnego dzieła, a jednocześnie dowodem niezwykłej konsekwencji performera.

Kiedy teraz, po latach, po lekturze Kronosa, czytam Opętanych, zakładając, że mam do czynienia z zaszyfrowaną powieścią gejowską, sama się dziwię, jak właściwie natychmiast po przyjęciu tej hipotezy ekscentryczne, trudne do wyjaśnienia elementy powieści znajdują przekonywające wyjaśnienie. Jeśli Maja i Marian są chłopcami, to przenikamy bez trudu sekret ich zmiennych, gwałtownych emocji i zachowań - naprzemienne ataki nieodpartego pragnienia i zażartej agresji - obserwujemy ich bunt przeciw pożądaniu, którego nie chcą, które ich stygmatyzuje. Rozumiemy, że rozpoznają się nawzajem w swoim homoseksualnym pragnieniu, staje się jasne, co znaczy ciągle powtarzane zdanie, że są do siebie podobni. Rozumiemy, dlaczego tuląc się wieczorem w szafie, odpychają się następnego dnia; dlaczego Maja nie potrafi porozmawiać z matką, dlaczego jej ojciec - na wszelki wypadek -

\footnotetext{
${ }^{1}$ W. Gombrowicz, Testament, Warszawa 1990, s. 15.
} 
nie żyje (ojcowie są zazwyczaj gorszymi homofobami niż matki), jakie znaczenie w powieści ma temat prostytucji będącej - być może - przeszłością Leszczuka (chłopiec od podawania piłek w klubie tenisowym mógł zarabiać również w inny sposób) oraz tym, co czeka Maję w Warszawie.

Jak wiadomo, również wątek gotycki Opętanych można bez trudu związać z problematyką gejowską - horror gotycki jest często opisywany przez badaczy queerowych jako gatunek wyrażający - i maskujący - lęk twórców przed swoim pragnieniem ${ }^{2}$.

Poetyka mojej ulubionej sceny balu w Syrenie da się określić jako campowa - tak można potraktować intensywne skarnawalizowanie tego fragmentu, jego dysonansowość, nieustanne przechodzenie od melodramatu na serio do szyderstwa z melodramatu. Słowa śpiewanego przez orkiestrę tanga wypowiadają najważniejszą kwestię powieści kluczową: wszechobecny u Gombrowicza, bardzo szczególny, sadomasochizm związków miłosnych.

W warszawskiej części Opętanych, zwłaszcza w scenie balu dla kelnerów, camp staje się narzędziem terapeutyzowania ironii jako nerwicy natręctw, jest remedium na przymus spiętrzania błyskotliwych replik w niekończące się kaskady. W enklawie dobrej złej powieści Gombrowicz nie musi się kłuć do krwi, ma prawo załkać nagle, a potem wrócić, jak gdyby nigdy nic, do pierwszorzędnej szermierki z geniuszami.

Znaczenie tego, co zrobił Gombrowicz w Opętanych, zwłaszcza w warszawskiej części tej powieści, można lepiej zrozumieć, gdy zestawi się tę powieść ze Zmowa mężczyzn Jarosława Iwaszkiewicza. Oba teksty bliskie są wyjawienia sekretu, którego ostatecznie nie wypowiadają. Męska homoseksualność w tamtym okresie skazywała zazwyczaj na życie w sekretnej sferze związków i kontaktów seksualnych mężczyzn i chłopców z rozmaitych warstw społecznych. Niejawność i stabuizowanie nieheteronormatywności spychało homoseksualistów w sferę na poły przestępczą. I te realia dość konsekwentnie oddają obie powieści. W Zmowie mężczyzn i w Opętanych poznajemy bohaterów, którzy w pogoni za miłosną przygodą, przekraczają granice w ryzykowny sposób. Obie powieści ukazują świat skrótu społecznego, nagłego zetknięcia się w łóżku - albo w krzakach - klasowo i kulturowo obcych.

Są jednak istotne różnice - powieść Iwaszkiewicza jest familiarna, wszyscy w niej rozmawiają otwarcie o swoich najskrytszych sekretach (poza homoseksualnością), rozmaite czułości krążą w powietrzu. Emocji i pragnień jest tak dużo, że dla kobiet - w drugiej kolejności, bo powieść jest ostentacyjnie męskocentryczna - też ich starcza. Prawie kastowe, postfeudalne społeczeństwo dewastują, ale i łączą, nocne przemarsze orszaku Dionizosa.

2 Por. E. Kosofsky-Sedgwick, Between Men: English Literature and Male Homosocial Desire, New York 1985, s. 83-96. 
Iwaszkiewicz jest liryczny społecznie, czego w żadnym razie nie da się powiedzieć o Gombrowiczu. Autor Ferdydurke trzeźwo analizuje w Opętanych napięcie między tym, co heteroseksualne, hierarchiczne, kastowe, a tym, co homoseksualne, subwersywne $\mathrm{i}$ anarchiczne. Ważnym aspektem pragnienia, które rządzi bohaterami Gombrowicza, jest różnica społeczna. Inność klasowa uruchamia pożądanie w niewiele mniejszym stopniu niż wybór obiektu tej samej płci - przypomnijmy sobie eleganckiego bohatera opowiadania $\mathrm{Na} \mathrm{ku}$ chennych schodach, którego pociągały jedynie najordynarniejsze kuchty. Jeśli czytamy Opętanych jako zaszyfrowaną powieść gejowską, pierwszoplanowa okazuje się kwestia uwikłania homoseksualnej orientacji w kontekst społeczno-kulturowy, w gorszość i wyższość klasową, w nagłą konfrontację kochanków o zróżnicowanych kapitałach kulturowych.

\section{III}

Sądzę, że utajony romans gotycki pełni w twórczości pisarza funkcję szczególnej mapy, panoramicznego obrazu ukazującej złożone pole Gombrowiczowskich pragnień i uczuć. W Opętanych pojawia się ciągłość i rozległość nieobecna gdzie indziej, a pisarz składa tu dość obszerne wyjaśnienia. Mamy okazję zobaczyć to, co autor Ferdydurke usuwa (albo znacząco modyfikuje) z innych utworów, z innych miejsc: jednym z przekształcanych (deformowanych) elementów jest upływ czasu: Gombrowicz konsekwentnie usuwa szersze ramy i perspektywy czasowe z tekstów pierwszoplanowej awangardowej twórczości.

Kiedy wymiar ten albo znika, albo jest poważnie przekształcony - przypomnijmy sobie trzydziestoletniego narratora Ferdydurke, który za sprawą dekretu autora stał się nagle siedemnastolatkiem - czytelnicy doznają zaburzeń lekturowego i egzystencjalnego błędnika, nagle tracą równowagę. Zanika w nich zdolność odczuwania pierwszej, spontanicznej empatii wobec bohaterów i łatwość orientowania się w świecie przedstawionym, poddani Gombrowiczowskiej odmianie efektu obcości, podporządkowują się woli autora/narratora.

Na pierwszym planie szczególnej mapy, którą są Opętani, prezentują się dwa rodzaje relacji kochanków wysokich i niskich, w tle funkcjonują również inne związki. Te dwa rodzaje pierwszoplanowych związków to, z jednej strony relacje seksualizujące społeczną przepaść a z drugiej strony związki rówieśników dążących do unieważnienia różnicy klasowej.

Pierwszy rodzaj wykorzystuje do tworzenia napięcia libidalnego hierarchiczną różnicę, co powoduje, że para wyższy-niższy układa się w związek sadomasochistyczny. Następuje w nim ciągła wymiana na pozycji miłosnego dręczyciela i dręczonego. Tak jest w związku księcia i Frania. Wprawdzie na pierwszym, dosłownym planie fabularnym relacja Holszańskiego i chłopca nie jest związkiem erotycznym, jednak powrót tej sceny jako jednoznacznie miłosnej - nocne wizyty 
dorosłego kochanka u śpiącego efeba w Trans-Atlantyku i Pornografii-pozwala w taki sposób interpretować relację lokajczyka i arystokraty; zwróćmy także uwagę, że Holszański pisze na murze podziemnego korytarza namiętne listy do zaginionego z całym miłosnym, melodramatycznym anturażem.

Przewaga społeczna księcia pozwala mu męczyć i upokarzać Frania, ale siła pożądania i sekret tego pragnienia wydaje mężczyznę w ręce wyrostka, który autodestrukcyjnie mści się na arystokracie. Różnica wieku ma w tym układzie góra-dół wielkie znaczenie, w wymiarze społecznym dojrzałość czy starość wzmacnia przewagę, ale w logice pożądania wiek jest słabością starszego. $\mathrm{W}$ ramach tego mechanizmu im gorzej społecznie, tym lepiej seksualnie. Feudalizm, bezlitosna hierarchia społeczna, produkuje rozkosz za pomocą męki. Zwróćmy uwagę, że choć Gombrowicz seksualizuje przepaść społeczną i różnicę wieku, to w pisarstwie autora Ferdydurke nie ma pederastii. Nie ma jej klasycznej wersji, znanej od czasów starożytnej Grecji. Dojrzały nie edukuje efeba, nie angażuje się w jego rozwój, wprost przeciwnie, rozkoszuje się niższością chłopca, jest mu ona potrzebna do osiągnięcia satysfakcji seksualnej. Tylko w Opętanych słyszymy skargę młodszego na tę sytuację. Chłopiec-kamerdyner Grzegorz powtarza profesorowi Skolińskiemu jego słowa - mówi o zablokowaniu, mówi o krzywdzie: „ojciec mnie wychowania nie dał, wstydzi się mnie, więc taki jestem!’’3.

Pederastia, zbliżona do klasycznego greckiego znaczenia tego terminu, jest za to częścią biograficznego doświadczenia Witolda Gombrowicza. Kiedy w latach 30. utworzył osobny stolik w Ziemiańskiej, nauczał przy nim i uwodził młodszych; kiedy po wojnie przyjeżdżał do Tandilu, stawał się wakacyjnym Sokratesem dla miejscowych nastoletnich. Kiedy wyjeżdżał z Argentyny, żegnała go gromada zafascynowanych nim uczniów. A już po latach zobaczymy, jak przez karty Kronosa przesuwa się tłum, anonimowych najczęściej, chłopców z ludu. Buchalteryjna lakoniczność schematycznych zapisów kroniki czyni młodych zawsze takimi samymi, wymienianymi bez końca. W rezultacie narrator Kronosa ma coś z seryjnego mordercy, a zarazem z wuja Konstantego, kiedy ten w ostatniej części Ferdydurke mówi:

- Twój przyjaciel - rzekł życiowo i arystokratycznie zarazem - pede... pede... [...] No, żeby panie się nie dowiedziały. Książę Seweryn także lubił sobie od czasu do czasu!

Wyciągnął przed siebie długie nogi. Ach, z jakąż arystokratyczną maestrią to wyrzekł! Z jakimż wyrobieniem pańskim, na które złożyło się czterystu kelnerów, siedemdziesięciu fryzjerów, trzydziestu dżokejów i tyleż maître d'hotelów $[\ldots]^{\prime \prime 4}$.

${ }^{3}$ W. Gombrowicz, Dzieła, t. XI: Opętani, Kraków 1994, s. 133. Dalsze cytaty z tego wydania identyfikowane w tekście numerem strony.

${ }^{4}$ Idem, Dzieła, t. II: Ferdydurke, Kraków 1986, s. 219. 
Miętus w Ferdydurke chciał od nastoletniego parobka przyjaźni i seksu jednocześnie, jednak nic z tego nie wyszło, bo w zakończeniu narrator zostawił swojego sobowtóra na lodzie. Od tego, który próbował po...bratać się z parobkiem, uciekł do budzącej w nim wstręt panienki ze dwora. „Koniec i bomba a kto czytał ten trąba" - tak Gombrowicz uciął, można powiedzieć, panicznie, powieść, ale nie sprawę, nie wielokształtne pragnienie, które w każdej swojej formie było inne, niż powinno być. Wrócił do niego w swoim literackim trzynastym miesiącu - tu bowiem dochodzi do po...bratania się rówieśnych kochanków, obok feudalnych (w psychospołecznym sensie sadomasochistycznych) związków pojawia się w Opętanych inny pierwszoplanowy i ważny rodzaj relacji: Leszczuk i Ochołowska dążą do anarchicznego związku równych.

W wiele lat po katastrofie związku księcia i Frania kwitnie ciernista miłość Mariana i Mai. Rozwija się w cieniu ponurego zamczyska, w sieci starych i nowych podziałów hierarchicznych fabrykujących miłosne relacje. Gombrowicz w niezmordowany sposób ukazuje jak stratyfikacja społeczna kształtuje erotyczne i matrymonialne wybory - widać to w przesyconej prostytucją warszawskiej przestrzeni, widać w Połyce (zwłaszcza gdy Maja spotyka przyjaciółkę, która pogodnie, jak gdyby nigdy nic, zakochuje się w chłopcu ze swojego środowiska, a Maja zastanawia się, dlaczego ona tak nie potrafi), a jednak wraca ciągle do życiodajnej, choć groźnej, egalitarności eksplodującej w ostatniej części Ferdydurke.

Odmienność Opętanych w stosunku do wcześniejszych i późniejszych utworów pisarza najlepiej widać $\mathrm{w}$ sposobie, w jaki autor powieści dla kucharek ukształtował obraz związku Holszańskiego i Frania. Wyłaniają się z opowieści kamerdynera Grzegorza monotonne i żałosne sceny, dobiegają z niej krzykliwe i thumione lamenty: jakby bez końca słuchamy skarg ambitnego chłopca zamkniętego w kuchni i kredensie, jesteśmy świadkami bezradnego gniewu Frania i obserwujemy dramatyczny zwrot, gdy chłopiec dowiaduje się, że nie jest bezsilny. Od tego momentu lokajczyk autodestrukcyjnie mści się na krzywdzicielu, wykorzystując jego miłość:

Aż tu, jak dziś pamiętam, przychodzi Franuś do kuchni nie ten sam. Uśmiecha się tak jakoś słodkawo, a złośliwie, zadowolony taki, a zły, że aż mnie tknęło.

Grzegorz zniżył głos i przeżegnał się nieznacznie.

- Od tej to chwili się zaczęło! - rzekł uroczyście. - Odtąd ten diabeł się stał!

Więc powiadam, że przyszedł do kuchni i mówi:

- No, teraz się z nim porachuję!

- Z kim się porachujesz? - mówię, a on na to:

- Z księciem, moim ojcem.

- Uważaj, żeby cię na zbity pysk nie wygonił - mówię mu, bo mnie nerwy psuł tym gadaniem. Ale on uśmiecha się tylko i mówi:

- On mnie nie wygoni, choćby chciał. 
- A dlaczego ma cię nie wygonić?

- Bo mnie kocha.

- Żeby ci tylko z tej miłości w zęby nie dał! - powiadam, a on wtedy:

- Możecie, Grzegorzu, przyjść w nocy do mnie i zobaczycie na własne oczy, jak mnie kocha.

Zainteresowałem się i w nocy stanąłem se za drzwiami, jak mi kazał. Patrzę, a tu książę nadchodzi boso, po cichutku. Przybliżył się do łóżka, na którym Franek spał, zbliża się, mówię, do łóżka ze świecą, długo się patrzy na niego, wzdycha, coś do siebie szepce i tak ciut, ciut palcami po włosach go gładzi - a łzy mu ciekną po twarzy, gładzi i ślocha - ślocha i gładzi... (s. 132-133).

Długo bezradnie cierpi młodszy, a potem bezsilnie zmaga się z bólem starszy. Obaj dążą do katastrofy zarówno osobno, jak i w najściślejszym splocie: chłopiec chce popełnić samobójstwo, żeby ugodzić w księcia. W relacji o sprawie Frania i Holszańskiego natrafiamy ciągle na grube złogi czasu: wiekowy lokaj opowiada staremu profesorowi o dramacie sprzed kilkudziesięciu lat narastającym latami w przestrzeni gotyckiego zamczyska. Czas, wyciśnięty zazwyczaj z Gombrowiczowskich fabuł, dostajemy tu w jednym dużym kawałku.

W dobrej złej powieści pojawia się także - obok pierwszoplanowych związków - ślad klasycznej pederastii: mam na myśli duety Leszczuka i Skolińskiego oraz Mai i Hińcza, dwie pary nauczycieli i uczniów, symbolicznych ojców i synów. Tutaj również powraca upływ czasu, tym razem oznacza on kumulację wiedzy i doświadczenia. Dzięki nim mistrzowie rozpoznają zagrożenia i mogą pomagać młodym. Na wyrazistym, warszawskim tle (stematyzuje się ono w Kronosie) pojawia się mrowie męskich (a czasem kobiecych) przelotnych kochanków, w tym także prostytutek. Dzięki temu, że w innych związkach płynie czas, możemy zobaczyć, że w przygodach i transakcjach nie ma go prawie wcale.

Gotycka powieść jak magnes przyciąga i zbiera elementy, gdzie indziej sfragmentaryzowane i rozsypane. Pisarz zapisał tu - ku pamięci i z myślą o jakiegoś rodzaju rekonstrukcji - wątki, które potem zanikają, a które wcześniej ukazywał z innej perspektywy. Z czasem bowiem w Gombrowiczowskich powieściach pozostaje, skadrowana tylko w jednym ujęciu, seksualność feudalna. W Trans-Atlantyku i Pornografii narrator poprzez odmienne wersje swoich delegatów na kraj (sobowtórów takich jak Miętus) ukazuje dorosłego miłośnika inscenizującego ekscytujące go sceny z udziałem młodych (jak wiemy, pisarz zanurza posłańców w odmętach świata przedstawionego i zawsze gotów jest ich poświęcić). Młodsi pojawiają się w Trans-Atlantyku i Pornografii jako unieruchomiony, zfragmentaryzowany obiekt seksualny, jako chwilowa własność starego w fazie sadystycznej. W ten sposób relacja, która potraktowana procesualnie, widziana w perspektywie upływającego czasu, z uwzględnieniem reakcji, uczuć i pożądań obu stron (z założeniem, że młodzi mają swoje pragnienia) jest relacją sadomasochistyczną ze zmiennym obsadzeniem roli sadysty i ma- 
sochisty, w Trans-Atlantyku, a zwłaszcza w Pornografii, sprowadzona zostaje do jednego usztywnionego segmentu sadomasochistycznej procesualności feudalnej. W tych dwu powieściach pojawiają się skrawki - pornograficzne sceny wyłącznie teraźniejszego czasu dające rozkosz dorosłemu miłośnikowi.

Wyjątkowość Opętanych polega nie tylko na tym, że to powieść popularna, w jakimś sensie naiwna (czym jest jednak naiwność, która następuje po jednej, a przed drugą falą tekstów spod znaku podejrzliwej ironii, a czasem rozpaczy?), ale także na tym, że to ostatnia przedwojenna, przedemigracyjna powieść Gombrowicza. Zaryzykowałabym pogląd, że ta graniczna powieść jest względnie szczęśliwą chwilą, bo ukazuje podmiotowość piszącego i zapisanego w fazie - również względnego - bezpieczeństwa. Ekstremalnie trudne warunki odtworzonego w Argentynie życia spowodowały, że objawy straumatyzowania, lęk, konieczność głębokiego ukrywania się powróciły wzmocnione, zwielokrotnione i w części przekształcone. Na chwilę jednak, w Opętanych, pisarz zmienia taktykę ukrywania się na mniej głęboką, bardziej zewnętrzną, polegającą ,zaledwie" na publikowaniu pod pseudonimem brukowej powieści w warszawskiej i radomskiej popołudniówce. Pisarz obywa się tu (prawie) bez dwu swoich najważniejszych - wewnętrznych, literackich narzędzi obronnych: bez konstruowania kapsuły i bez rozsypania fragmentów.

Gombrowiczowska odmiana awangardowego, modernistycznego pisarstwa polega bowiem na tym, że narracje pisarza ujawniają istnienie traumy, a zarazem są ukształtowane, zdeformowane przez zaszyfrowane wyrażanie pragnienia niemożliwego. Jednocześnie prawie w każdym $\mathrm{z}$ nich toczą się procesy autoterapii, procesy rekonstrukcji podmiotowości zapisującej się i zapisanej w tekście. Procesy terapeutyczne towarzyszące narracyjnym symptomom straumatyzowania i szyfrom zakazanego pragnienia nie są w pełni skuteczne, nie prowadzą do żadnego jednorazowego, finalnego ,wyleczenia” i wypowiedzenia, wprost przeciwnie, są częściowe i dlatego muszą być ciągle powtarzane - w coraz to nowy sposób, w innym wariancie nieuchronnego sfragmentaryzowania. Współwystępowanie objawów traumy i oznak przepracowywania rozgrywa się zarazem w skali mikro i makro, to znaczy w obrębie jednego utworu i w przestrzeni całej twórczości pisarza (z podziałem na fazy) - w innym rytmie, w sposób charakterystyczny dla wielkiej i małej skali. W awangardowej prozie przedwojennej pojawia się obok rozsypywania segmentów także fantazmatyczny obraz bezpiecznej kapsuły, potem azyl skondensowany zostaje do esencjonalnej mocy Gombrowiczowskiego głosu, to on staje się mikrokapsułą.

W Opętanych - tak jak w niektórych opowiadaniach z Pamiętnika z okresu dojrzewania - nie mówi Gombrowiczowskie ,ja”; nie rozlega się Gombrowiczowski głos dobitnie głoszący Gombrowiczowską prawdę, w prawie dowolny sposób kształtujący czas świata przedstawionego. W zdecydowanej większości utworów pisarza „wisimy” na tym głosie, apodyktyczność narratora zdaje się ofiarowywać czytelnikom wysepkę ocalenia. Niżej, w świecie przedstawionym, kłębi się rzeka ciemności: 
Krzyżowa to była droga i powolna, najcięższa z dróg, jakie kiedykolwiek przebyłem; dowiecie się jeszcze o mych przygodach w prerii i pośród Murzynów, ale nie dorówna Murzyn tej peregrynacji przez bolimowskie podwórze. Nigdzie - gorszego egzotyzmu. Nigdzie - zjadliwszej trucizny. Nigdzie pod stopami nie zakwitały bardziej niezdrowe fantazmy i kwiaty - orchidee, nigdzie - tyle orientalnych motyli $[\ldots]^{5}$.

Oprócz fałszywej zapowiedzi (po Ferdydurke nie dowiemy się wiele „o przygodach bohatera i narratora w prerii i pośród Murzynów”, obraz odsyła raczej do pisarskiej przeszłości Gombrowicza, fantazmatyczna wizja egzotycznych motyli i orchidei pojawiła się bowiem w zakończeniu Zdarzeń na brygu Bunbury) fragment ten charakteryzuje obecną sytuację i perspektywę narratora/autora - przemierza on bolimowski czarny ląd jako członek mikroekspedycji, antropolog i kolonizator jednocześnie (metafora ta ujawnia dwuznaczność Gombrowiczowskiej enklawy).

W brukowcu jest inaczej. Inaczej, niż było wcześniej, i inaczej, niż będzie później. Bohaterowie, zwłaszcza tytułowi opętani - Franio, Leszczuk, Maja - okazują się pogrążeni w odmętach niewiedzy, dezorientacji, niemożliwości ustalenia czegokolwiek na pewno, a bezosobowy, pozornie nijaki (sprawnie jednak oddający perspektywę Mai i Leszczuka przede wszystkim) narrator powieści popularnej nie próbuje jednoznacznie zdefiniować licznych niejasnych sytuacji, wprost przeciwnie, do chaosu poznawczego i aksjologicznego (panującego w powieści za sprawą bohaterów) dorzuca coraz to nowe nierozstrzygnięcia, tym razem zanurza się w chaosie świata przedstawionego bez żadnych, czy prawie żadnych, zabezpieczeń. Tę niezabezpieczoną słabą pozycję narratora widać bardzo wyraźnie w kwestiach dotyczących dzieł sztuki i metafizyki. Ani opowiadacz, ani jego bohaterowie nie potrafią ustalić niczego na pewno, zarówno w sprawie nadprzyrodzonego czynnika wpływającego (może) na zdarzenia rozgrywające się na zamku, jak i w kwestii wartości dzieł sztuki tam zgromadzonych.

Uderzają zwłaszcza ambiwalencja i zmienność (aksjologiczna i emocjonalna) ujawniające się w scenie balu w Syrenie. Wprawdzie i tutaj pojawia się motyw mikrowyprawy antropologicznej, tym razem jednak ekspedycją dowodzi Maja, postać zanurzona bez reszty w nieprzejrzystym świecie. W kulminacyjnej scenie rozdziału jakby wyjętego z wirtualnych „Tajemnic Warszawy” bohater(ka) zaprasza do tańca ukochanego mężczyznę. W tangu autor topi kochanków, balowe towarzystwo i siebie samego, w naprzemiennych falach jasności i ciemności, w fazach usztywniania i upłynniania - uczuć, ekspresji i poglądów. Tańcząca para, niezwykła i piękna, oraz skarnawalizowany tłum gości stapiają się nagle w świąteczną, radosną jedność:

${ }^{5}$ W. Gombrowicz, Ferdydurke, s. 225. 
Tańczył z nią sztywno i ostrożnie [...]. Prowadził ją z dala od siebie i taniec jego był nieporadny - raczej obrządek niż taniec. Maja wyczuwała jego ruchy. Były to ruchy... uczciwe. Były to ruchy porządnego człowieka z gminu, pełnego szacunku dla tańca, naiwne, ale szczere.

Lecz ona poczuła się naraz wyniesiona na same szczyty muzyki i strącona w jej najciemniejsze przepaści. Świetna tanecznica, przyczaiła się i utaiła w sobie! Powoli, nieznacznie jęła go wciągać w zaklętą krainę tańca, tam, gdzie ruch przemienia się w melodię, melodia w ruch. To już nie on ją prowadził. Ona jego prowadziła.

I podstępnie, z wolna wprowadzała go w śpiew skrzypiec, w grzmot bębna, w nagłe, niespodziewane głosy fletów i w to wszystko, co się tam działo w tej muzyce.

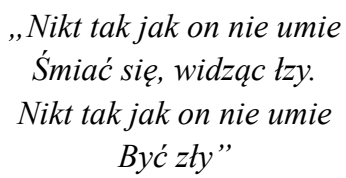

- śpiewali grajkowie.

A Maja ze zmarszczonymi brwiami, poważna, śledziła, jak on się budzi do tańca - i z niemym szczęściem odnajdywała w nim subtelność, wrażliwość, poezję, zespolenie się z dźwiękiem urodzonego tancerza. Skąd on to wszystko wiedział? Jakim cudem to rozumiał! Jeszcze to niech zrozumie! Jeszcze to przejście tonacji! I podszeptywała mu całą swoją istotą znaki tajemne śpiewu, który ich brał w posiadanie.

A muzykanci zauważyli tę parę i może uderzyło ich „podobieństwo” tych dwojga, a może sam taniec... dość, że orkiestra naraz jęła grać zupełnie inaczej, niż dotychczas, stała się wymowna. Uderzyła w tańczących natężoną falą, wiodła ich, stowarzyszała się z nimi. Inaczej brzmiały flety. Inny był dźwięk saksofonu, a skrzypce i wiolonczela, jak pijane własną pięknością, prześcigały się w rozkoszy.

\section{„Lecz gdy zatańczy ze mna, \\ To wargi moje bledna \\ Woczach się robi ciemno \\ I czuję tylko jedno..."}

Sala kołysała się i płynęła. Czyż to oni zarazili inne pary, czy ich zapamiętanie udzieliło się wszystkim? Było coś takiego, co przyspieszało bicie serca, oszałamiało i zmuszało do absolutnego zaprzepaszczenia się w tańcu (s. 227-228).

Żywy, gorący prąd bijący od Mai i Leszczuka, chwilowa pewność panny Ochołowskiej, że wie, kim jest jej ukochany, szybko jednak ulatują, kiedy muzyka przestaje grać. Balowicze natychmiast zwracają się przeciw ekstatycznie wyniesionej parze, a następny dramatyczny epizod (Marian zostaje niesłusznie oskarżony o kradzież portfela) jeszcze raz zdezorientuje bohaterkę. Otaczająca bohaterów zbiorowość raz jest podstępna i zła, żeby za chwilę okazać się świętującą radośnie wspólnotą. 
Zwróćmy uwagę, że w innym języku Gombrowicz powtarza tu rytm charakterystyczny dla końcowych partii Ferdydurke. Tam mieliśmy do czynienia z fazami światła i ciemności, groźby i nadziei: pozytywnie waloryzowana noc chwilowo wyzwalała narratora (i jego delegata na kraj, Miętusa), ujawniała podskórne moce. W Ferdydurke narrator ciągle wystawał jednak ponad świat przedstawiony, a w powieści dla kucharek, opowiadacz, tak jak młodzi bohaterowie, jest zanurzony zupełnie, zdekoncentrowany i niepewny siebie: podobnie jak Marianowi imponują mu rozmaici celebryci, ważne okazują się dla niego pieniądze i nieograniczony dostęp do ich używania. Opowiadacz zdaje się należeć - tak jak Franio, Maja czy Leszczuk - do łątek jedniodniówek bez reszty zatraconych w codziennej niepewności.

A jednak nie do końca tak jest. Kiedy zrozpaczona Maja spotyka w tramwaju jasnowidza Hińcza, pyta go o najważniejsze dla siebie sprawy:

- Czy pan wierzy, że są rzeczy złe i dobre [...]?

- Dużo jest jeszcze na świecie tajemnic zupełnie niepojętych dla umysłu ludzkiego - odparł. - [...] Ale im więcej jest tajemnic, tym bardziej jedno staje się oczywiste i jasne, a mianowicie - najprostsze nakazy sumienia, prawo moralne. Wielu rzeczy nie wiemy, ale co jest dobre, a co złe - to wiemy od razu i na pewno (s. 271).

Po dołączeniu do ekipy bohaterów słynnego widzącego, prawie pod koniec powieści, narrator przybiera nagle inny ton, ton pewności moralnej, który nie ma nic wspólnego ze zwyczajnym apodyktyzmem Gombrowiczowskiego ,ja”, znanym czytelnikom z innych utworów pisarza. Ton pewności moralnej jeszcze mocniej akcentują nieco późniejsze rozmyślania wizjonera:

Coraz wyraźniej ukazywała mu się pośród okropnych niejasności świata ta prosta i pewna prawda, że jedyną ostoją człowieka, jedyną jego bronią i prawem są wartości charakteru, a jedynym drogowskazem - moralność. Miał pewność, że jeśli Maja i Leszczuk uzyskają w sobie to dobre samopoczucie moralne - wyjdą zwycięsko z wszelkich trudności (s. 294).

Wprawdzie wraz z wkroczeniem Hińcza pojawia się (czy rodzi) stały schemat autora, poznajemy bowiem sobowtórową parę dorosłych bohaterów takich jak Gombrowicz i Gonzalo w Trans-Atlantyku czy Gombrowicz i Fryderyk w Pornografi - tym razem jednak para „starych” bohaterów zachowuje się inaczej, można powiedzieć, poczciwie. Skoliński i Hińcz wspólnie ratują Maję i Leszczuka, powstrzymując się od seksualnej instrumentalizacji młodych. Dzięki ojcowskim postaciom, pozostającym w kręgu altruistycznej pederastii, pisarz wprowadza, kuchennymi schodami, problematykę etyczną, która jest mu jakby zabroniona $\mathrm{w}$ jego pierwszoplanowej prozie zdominowanej przez seksualizację przepaści społecznej i różnicę wieku. 
We wcześniejszych opowiadaniach z Pamiętnika pisarz posługiwał się zazwyczaj deformacjami temporalnymi w taki sposób, że dla bohaterów rozchodził się porządek zdarzeń i emocji; jak we śnie ból czy rozkosz postaci łączyły się ze faktami, które ich nie wywołały, nie pasowały do nich. Ten sposób postępowania jest wyrazisty zwłaszcza w Pamiętniku Jakuba Czarnieckiego (ważny jest także w Biesiadzie u hrabiny Kottubaj czy Zbrodni z premedytacją. Właściwie wszystkie nowele debiutanckiego tomu warto czytać inwersyjnie, zakładając konieczność radykalnej rekompozycji porządku znaczeń i energii libidalnych).

Na pierwszy rzut oka Pamiętnik Jakuba Czarnieckiego jest groteskową, pośpieszną mieszaniną biograficznego schematu pamiętnikowego z na poły satyrycznym esejem na temat uprzedzeń i zabobonów społecznych. Ten splot gatunków rodzi enigmatyczną opowieść o narratorze i bohaterze, który długo zdaje się nie mieć żadnych pragnień i emocji. Pod koniec noweli marionetkowy bohater nagle ożywa, gdy zraniony zostaje na wojnie jego towarzysz broni. Bomba pozbawia żołnierza nóg, i jak się możemy domyślić, kastruje:

Wtem pocisk armatni nadlatuje, pęka, wybucha, ucina ułanowi Kacperskiemu obie nogi, rozrywa brzuch, a ten z początku traci się, nie pojmuje, co się stało, a w chwilę potem też wybucha, ale śmiechem, też pęka, ale ze śmiechu! - trzymając się za brzuch, tryskający krwią, jak fontanna, piszczy i piszczy humorystycznym, wrzaskliwym, histerycznym, krotochwilnym dyszkantem - długie minuty! ${ }^{6}$

Narrator wybucha wtedy opóźnioną ekspresją, a czytelnicy odzyskują dostęp do wiedzy o wypartym bólu tytułowego bohatera: od początku cierpiał. Dziecko domowej wojny, dziecko wstrętu arystokratycznego ojca do żydowskiej matki, odnajduje możliwość wypowiedzenia swojego wewnętrznego i seksualnego unicestwienia w straszliwym obrazie militarnej śmierci. Uświadomienie sobie cierpienia tytułowej postaci może wyzwolić opóźnioną empatię czytelników, a wraz z nią pojawia się miejsce na odzyskany odruch moralny. Zaraz po wypowiedzeniu męki narrator porzuca ,narzeczoną”, heteroseksualną miłość i małżeństwo.

W innym opowiadaniu z Pamiętnika, w Przygodach, baśniowy dar od fantazmatycznego białego Murzyna - dostępna ciągle na nowo, zmieniająca formy kapsuła ratownicza - pozwala narratorowi oddalać się bezpiecznie za każdym razem, gdy zagraża mu „,normalne” życie.

Powieść dla kucharek jak magnes wyciąga i rekomponuje ukryte ślady z innych utworów pisarza - z Pamiętnika z okresu dojrzewania, z Iwony, księżniczki Burgunda, z Ferdydurke, Operetki. Otrzymujemy bowiem w Opętanych - w jednym melodramatycznym (czasem campowym) kawałku dostęp do bólu, pragnień i rozkoszy. Obserwujemy upływ czasu. Ta wiedza nie powinna pozostawać na swoim miejscu, w brukowcu, wprost przeciwnie,

${ }^{6}$ W. Gombrowicz, Dzieła, t. I: Bakakaj, Kraków 1986, s. 27. 
powinna nasycić ważne Gombrowiczowskie teksty. Powinna - jak wiele lat wcześniej zapowiada pisarz w Pamiętniku Jakuba Czarnieckiego - nastąpić eksplozja i dyslokacja znaczeń i emocji.

Tak jak o tym wspomniałam, Opętani pozwalają także, dzięki perspektywie pewności moralnej (osiągniętej po dołączeniu do ekipy bohaterów jasnowidza Hińcza), ujawnić nikłość (czy może raczej retardacyjny charakter) perspektywy etycznej (nie)obecnej w powojennych powieści Gombrowicza. Ten aspekt łączy się, jak sadzę, z usztywnionym eksponowaniem (wyłączonej z sądzenia) jednej sekwencji seksualnego scenariusza feudalnego: rozkoszy dorosłego w fazie sadystycznej. Dzięki genologicznej dywersyfikacji powojennych dzieł pisarza nie dochodzi do zatrzymania się libidalnego ruchu Gombrowiczowskiej twórczości w tym jednym punkcie. Jego dzieło krąży pomiędzy sprzecznymi treściami zawartymi w utworach różnych gatunkowo. Otóż skamieniałej rozpaczy Pornografii i Kosmosu odpowiada anarchiczny witalizm końca Operetki: w dramacie powraca temat po...bratania - finał utworu to miłosny sojusz zmartwychwstałej Albertynki z rówieśnymi złodziejaszkami.

Równolegle Gombrowicz pisze dziennik, w którym podejmuje działania zainicjowane przez duet Hińcza i Skolińskiego. $Z$ połączonych pozycji jasnowidza i profesora naucza pisarz, jak żyć - wszystkich razem (narodowo) i każdego z osobna. A po latach okazuje się, że do rozdzielonej gatunkami, tunelowej Gombrowiczowskiej dialogowości - rozmaite sprzeczne składniki, jak muzyczne motywy, długo prowadzi pisarz oddzielnie, jakby autystycznie - trzeba dołączyć jeszcze brutalną enigmę Kronosa.

Żeby nastąpił wybuch, łączący osobne składniki (jakby wsobne, asynchroniczne wobec siebie), powinniśmy potrząsać całością. Wtedy zrozumiemy jeszcze inaczej niż zazwyczaj niezwykłe gesty pisarza.

Na przykład początek Dziennika:

\section{Poniedziałek}

Ja.

Wtorek

Ja.

Środa

Ja.

$\mathrm{Ja}^{7}$.

Czy to powtórzone czterokrotnie ,ja” nie ogłasza wszem i wobec: „Ocalałem. Mimo wszelkich przeszkód, ocalałem. Wieści o śmierci autora okazały się mocno przesadzone”. To „ocalałem”, w polskich uszach rymuje się, może wcale nie tak świętokradczo, z wersem „ocalałem prowadzony na rzeź”.

\footnotetext{
7 Idem, Dzieła, t. VII: Dziennik 1953-1956, Kraków 1986, s. 9.
} 
Trauma, zakazane pragnienie, rozkosz. Ból, zagrożenie, rozpad, a zarazem uparta praca ocalania się i scalania ciągle na nowo, uparta walka o własną wielkość, o opóźnioną, pełną szacunku empatię czytelników - wszystko to toczy się od Pamiętnika Jakuba Czarnieckiego poprzez Pamiętnik z okresu dojrzewania do ostatnich wywiadów pisarza.

\section{Bibliografia}

Gombrowicz W., Dzieła, t. I: Bakakaj, Kraków 1986.

Gombrowicz W., Dzieła, t. II: Ferdydurke, Kraków 1986.

Gombrowicz W., Dzieła, t. VII-X: Dziennik, Kraków 1986-1992.

Gombrowicz W., Dzieła, t. XI: Opętani, Kraków 1994.

Gombrowicz W., Testament, Warszawa 1990.

Kosofsky-Sedgwick E., Between Men: English Literature and Male Homosocial Desire, New York 1985. 